\title{
REVIEW
}

\section{KONSEP EKONOMI KAPITALISME}

DERIL (90100118124)

\section{derilderil604@gmail.com}

Sistem ekonomi adalah sekumpulan komponen-komponen atau unsur-unsur yang terdiri dari atas unit-unit dan agen-agen ekonomi, serta lembaga-lembaga ekonomi yang bukan saja saling berhubungan dan berinteraksi melainkan juga sampai tingkat tertentu yang saling menopang dan memengaruhi.1 Sedangkan kapitalisme merupakan sebuah sistem organisasi ekonomi yang dicirikan oleh hak milik privat atas alat-alat produksi dan distribusi yang pemanfaatannya untuk mencapai laba dalam kondisi yang sangat kompetitif.

Jadi sistem ekonomi kapitalis adalah sistem ekonomi yang asset-aset produktif dan atau faktor-faktor produksinya sebagian besar dimiliki oleh sektor individu atau swasta. perekonomian yang memberikan kebebasan secara penuh kepada setiap orang untuk melaksanakan kegiatan perekonomian seperti memproduksi barang, menjual barang, menyalurkan barang dan lain sebagainya.

Sistem kapitalis memandang bahwa manusia adalah pemilik satu-satunya terhadap harta yang telah diusahakan. Tidak ada hak orang lain di dalamnya. Ia memiliki hak mutlak untuk membelanjakan sesuai dengan keinginannya. Sosok pribadi dipandang memiliki hak untuk memonopoli sarana-sarana produksi sesuai kekuasaannya. Ia mengalokasikan hartanya hanya pada bidang yang memiliki nilai guna materi (profit oriented).

\section{Ciri-Ciri Ekonomi Kapitalisme :}

a) Kebebasan memiliki harta secara perorangan 
Hak milik perorangan merupakan elemen penting kapitalisme. Dalam paham kapitalisme tidak berlaku istilah hak milik berfungsi sosial. Pemberian hak milik secara mutlak akan menciptakan perilaku individu untuk menggunakan semaksimal mungkin sumber daya yang dimiliki dan berdampak pada distribusi pendapatan masyarakat.

b) Kebebasan ekonomi dan persaingan bebas

Setiap individu berhak untuk mendirikan, mengorganisasi dan mengelola perusahaan yang diinginkan. Individu juga berhak terjun dalam semua bidang perniagaan dan memperolah keuntungan sebanyak-banyaknya. Negara tidak boleh campur tangan dalam semua kegiatan ekonomi dan persaingan bebas yang berorientasi mencari keuntungan, selama aktifitas yang dilakukan itu legal menurut perundangundangan yang berlaku di negara tertentu. Persaingan bisa terjadi antar produsen dalam menghasilkan produk, antar penyalur produk, antar karyawan untuk mendapatkan pekerjaan, bahkan antar pemilik modal, dan seterusnya.

c) Mementingkan diri sendiri.

Aktivitas individu diyakini tidak akan membawa kekacauan, bahkan sebaliknya akan membawa kemakmuran bangsa-bangsa.Adam Smith mengatakan "Bukan berkat kemurahan hati tukang daging,tukang pembuat bir dan tukang roti kita dapat makan siang, akan tetapi karena mereka memperhatikan kepentingan pribadi mereka. Kita bicarakan bukan kepada rasa kemanusiaan mereka melainkan cinta mereka kepada diri mereka sendiri”5

d) Perekonomian diatur oleh mekanisme pasar

Setiap harga barang yang ada dipasar sudah ditentukan oleh permintaan dan penawaran yang dilakukan secara bebas

e) Manusia dipandang sebagai mahluk homo-economicus, yang selalu mengejar kepentingan (keuntungan) sendiri6 
f) Campur tangan pemerintah minimum

Dalam sistem ekonomi kapitalis, yang sangat berperan adalah individu, bukan pemerintah. Pihak Pemerintah memberikan kebebasan kepada para pemodal untuk mengembangkan usahanya. Mereka dapat menguasai dan memajukan berbagai aspek ekonomi. Pembangunan sarana jalan, transportasi, berbagai gedung pemerintah dan usaha lainnya ditanangi oleh pihak swasta. Pemerintah tugasnya membuat regulasi untuk membayar pajak yang besar. Hasil dari pajak itulah digunakan untuk mensejahterakan rakyatnya Dengan kata lain, bahwa dalam sistem ini pemerintah bisa turut ambil bagian untuk memastikan kelancaran dan keberlangsungan kegiatan perekonomian yang berjalan, tetapi bisa juga pemerintah tidak ikut campur dalam ekonomi. 


\section{DAFTAR PUSTAKA}

Agustiati, Agustiati. "Sistem Ekonomi Kapitalisme." Academica 1, no. 2 (2009).

Azhar, Azhar. "Antara Ekonomi Islam dan Ekonomi Konvensional.” Islamika: Jurnal Ilmu-Ilmu Keislaman 17, no. 2 (2017): 1-16.

Effendi, Syamsul. "Perbandingan Sistem Ekonomi Islam Dengan Sistem Ekonomi Kapitalis dan Sosialis.” JRAM (Jurnal Riset Akuntansi Multiparadigma) 6, no. 2 (2019): 147-58.

Hasan, Zainol, dan Mahyudi Mahyudi. "Analisis terhadap Pemikiran Ekonomi Kapitalisme Adam Smith.” Istidlal: Jurnal Ekonomi dan Hukum Islam 4, no. 1 (2020): 24-34.

Itang, Itang, dan Adib Daenuri. "Sistem Ekonomi Kapitalis, Sosialis, dan Islam." Tazkiya 18, no. 01 (2017): 67-91.

Mujiatun, Siti. "Peran Pemerintah Tentang Pengembangan Perekonomian Dalam Perspektif Sistem Ekonomi Kapitalis, Sosialis, Dan Islam.” Jurnal Analytica Islamica 3 (2014): 90-107.

Parakkasi, Idris, dan Kamiruddin Kamiruddin. “Analisis Harga Dan Mekanisme Pasar Dalam Perspektif Islam.” Laa Maisyir: Jurnal Ekonomi Islam 5, no. 1 (2018). 